\title{
Speech Act of Refusal In Indonesian Talk Show As Art of Rhetoric
}

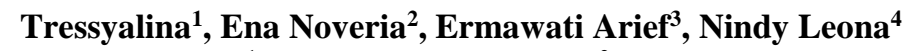 \\ \{tressyalina@fbs.unp.ac.id ${ }^{1}$, enanoveria@fbs.unp.ac.id ${ }^{2}$, ermawatiarief@fbs.unp.ac.id $\left.{ }^{3}\right\}$ \\ ${ }^{1,2,3}$ Lecturer, Faculty of Languange and Art, Padang State University, Padang, Indonesia
}

\begin{abstract}
Talking titles on television can be used as guidelines in developing language skills, ranging from interviewing skills, debate, and also speech art of refusal. The focus of the problem in this research is how to speech art of refusal contained in speech titles in Indonesia. The method used in this study is a qualitative method with a descriptive approach and data collection using the technique of listening and note taking. Based on this research, 29 speech act of refusal were found divided into 6 strategies, namely the speech act refuse strategy with a statement of denial, the direct speech act of refusal strategy, the speech act refuse by denial, the speech act refuse with clarification, the speech act refuse with a new statement, the speech act strategy refusal with promises in the future, and the speech act of refusal with the delegation of mistakes.
\end{abstract}

Keywords: Speech Act Refused, Talk Show, Rhetoric

\section{Introduction}

Language has an important role in human life. Language in linguistic studies is defined as an arbitrary system of sound symbols that humans use as tools for social interaction or communication tools. Through language a person can express the intention he wants to convey to the interlocutor or the speech partner. Speech delivered by the speaker should use good and correct language, in using context language it becomes something that must be considered so that what is conveyed is easily understood by the speech partner. The context used in a speech can affect the understanding of the speech partner of the speech that occurs in a speech event. Speech is a process of linguistic interaction in one or more forms of speech involving two parties, namely the speaker and the speech partner, in a time, place, and in certain situations. Speech events can occur anywhere and anytime, can be between students and lecturers, sellers and buyers, interviewers and resource persons, and so forth. Speech events built by both parties have a purpose to convey a specific purpose or goal[1].

Searle [2] explained that speech acts are theories that try to study the meaning of language based on the relationship of speech with the actions taken by the speaker. Correspondingly, Austin [3] argues that when someone tells something someone also does something on the basis of the speech, such as refusing something that is not desirable.

Lexically, rejection means the process, method, act of rejection, it can be said that the act of rejection speech is a way to express disapproval of the utterance partner's expressions. Eelen [4] states that rejection is an act that threatens the face of the speech partner. The rejection strategy must be understood by the speaker and the speech partner so that both the speaker and the speech partner do not lose a positive face. In line with the opinion of Eelen, 
states that speech acts refuse to possess traits that can threaten the face, speech partners. Rejection often involves a long sequence of negotiations, and the form and content varies depending on the conversation that arises [5].

According to Carla [6], in Japanese culture refusal is not only for requests or invitations, but can also be stated to refusals statement of speech partners. Japanese speakers express their cautious refusing in using speech strategies so as not to hurt the feelings of the speech partner. Apologies, expressions of regret, and self-deprecating comments are sometimes used to give a good impression of a refusal. In line with that, Durer [7] states that the act of refusing speech does not only occur between speakers and peer partners, but can also occur between speakers and speech partners of different ages. In his research, Durer examined the speech acts of refusal spoken by the Polish and Turkish people in English.

In line with Carla's opinion, Mahdiah [8] state that speech acts refuse not only to refusalt a request, invitation, suggestion, invitation, or offer, but also serves to reject an argument. Arguments often arise in a debate or discussion. Debate or discussion activities have been widely broadcast on television, one of which is in speech titles. Many speech titles are broadcast by Indonesian television, for example Mata Najwa, Alvin \& Friends, Satu Jam Lebih Dekat, Tea Time, Kick Andy, Apa Kabar Indonesia, Sudut Pandang, and Satu Meja.

From some of the expert opinions above, it can be concluded that the act of refusing speech is an utterance that can be spoken by the speaker if he wants to refusal the request, the offer of the speech partner, but there are several strategies that must be considered in refusing a speech in order to save the speech and the refusals speech can positive value.

Research related to speech acts refused in speech titles is very interesting to be studied and has been widely studied by previous researchers. Mushtaq [9] examined the act of refusing speech with the title "Analyzing The Speech Act Of Disagreement Produced By Iraqi Efl Learners: A Gender Study" in his study Mushtaq examined whether gender differences affect a person in refusing a speech, from his study Mushtaq concluded that gender has a significant and not significant effect on the attitude of someone in refusing a speech.

Ilmiani [10] also examined the acts of rejection which he gave the title "Politeness in Efl Refusals: The Comparison Between Indonesian and Thai Learners Of English", in his research Ilmiani examined how the rejection spoken by English students from Indonesia and Thailand, and from his research Ilmiani concluded that the two students used almost the same rejection strategy, but the politeness strategy was different.

Furthermore, Kanemoto [11] examined the same thing with the title "A Comparative Study of Refusal Assertion in the United States and Japan" in his research Kanemoto examined how the strategy of refusing utterances in the United States and Japan, from his research Kanemoto found that speech acts refused in The United States uses two formal strategies and in Japan uses three formal strategies.

Eslami [12] also examined the problems related to refusing speech acts with the title "Refusals How To Develop Appropriate Refusal Strategies", according to Eslami, this research departs from how speech acts reject is a speech that is difficult to express, because speakers must be able to maintain the feelings of the speech partner, as stated by Brown and Levinson [13], rejection is considered as one of the most threatening actions because it intrinsically threatens the face of the speech partner.

Iliadi [14] examined the same thing as the previous researchers with the title "Refusal Strategies In English And Russian", Iliadi examined how to express the rejection speech in English and Russian, and investigated the British and Russian refusal strategy from the perspective of cross-cultural communication. The research carried out by Iliadi aims to find similarities and differences between how to refusal requests, offers, and invitations in different 
social contexts in two languages and cultures. From his research Iliadi found that Russian speakers tended to use the word not followed by an apology or explanation, whereas English speakers strongly avoided the word no to refuse an utterance or request, English speakers preferred to use a combination of positive politeness strategies that were more typical of Russian speakers to save the face of a partner partner said.

In Indonesia, there are already several researchers who have examined this issue. Madihah [8] examined the act of refusing speech in the title of Mata Najwa with the title " Tindak Tutur Menolak dalam Gelar Wicara Mata Najwa serta Implikasinya ", in his research Madihah examined the act of refusing speech spoken by the source at the Mata Najwa title, from his research Madihah found 52 utterances that were spoken by the speakers.

Furthermore, research conducted by Hermaji [15] entitled " Tindak Tutur Penerimaan dan Penolakan dalam Bahasa Indonesia ", in his research Hermaji examined the act of acceptance and refusal in Indonesian as an effort to describe or describe the actual use of language in the community. Acts of acceptance and refusal in Indonesian can be seen that the form is very diverse and from his research, from his research Hermaji found 5 structures of acceptance and 2 structures of refusal.

Santoso [16] also examined with the title " Bentuk, Strategi Penggunaan, dan Kesantunan Tindak Tutur Menolak dalam Interaksi Antar Mahasiswa Prodi Sastra Prancis FBS UNNES ", in his research Santoso examined how the politeness of speech acts refused in French, from Santoso's research found that respondents preferred to use the single mode, which is the declarative mode of refusing requests.

Maryamah [17] examined the same thing with the title " Strategi Tindak Tutur Menolak Anak Usia 7 Tahun ", in his research Maryamah examined how a 7-year-old child refused an order, request, offer, or invitation if the child did not want to fulfill it, from his research Maryamah found that the speech act strategy of refusing 7 year olds was expressed through the use of the lingual element.

This research will also examine the same thing as the previous research, namely the speech act of refusing. But what distinguishes this research from previous research is the object to be analyzed. The research to be analyzed analyzes how speech acts refusal the eight speech titles found on television in Indonesia. Researchers chose the object of speech titles on television because today, television is the most popular media by all people and all ages. So the degree of speech broadcast by the television station can be used as a reference or guideline in refusing utterances, moreover television is a media that is seen by millions of pairs of eyes, of course the speaker must think of a rejection strategy like what should be said so as not to threaten the face of the speech partner. The results of this study will be implicated as the art of rhetoric in interviewing skills to reject an utterance, request, or offer of a speech partner.

\section{Methodology}

The method used in this research is descriptive qualitative method with a pragmatic approach. Qualitative research is research whose data are expressed in verbal form and analyzed without using statistical data [18]. Qualitative research is research in which data is in the form of words or images, so it does not emphasize numbers and aims to describe or describe the events that occur. The approach used in this research is the pragmatic approach. The pragmatic approach can be used in research where the object is in the form of speech acts, because speech acts are bound to the context and the context itself is the main subject in pragmatics [19]. 
Data collection and data analysis in this study used the note-taking technique with the following

steps.

1. Download the speech title video Mata Najwa, Alvin \& Friends, Satu Jam Lebih Dekat, Tea

Time, Kick Andy, Apa Kabar Indonesia, Sudut Pandang, and Satu Meja on www.youtube.com.

2. Listen to the video of the speech title that has been downloaded and identify the resource person's speech containing the speech act, then record it.

3. Grouping data into observation tables based on the type of speech act of refused it.

4. Describe data that has been grouped according to the type of speech act refused.

5. Pulling conclusions from data that has been found.

\section{Discussion / Analysis}

\subsection{Reaction Speech Act of Refusal in Indonesian Talk Show}

Interview skills that can be used as a guideline are interviews on television talk shows. Speech is an event that is broadcast to the public. The programs offered today are very varied and have become more interactive over the years. Starting from the monologue to the narrative that was replaced in the form of dialogue, such as: interviews, panel discussions, and audience participation in speeches (talk shows) [20]. In an interview, there are several reasons why the resource person must say a reject to fulfill the interviewer's request. In rejecting the interviewer's request, there are many strategies that can be used. The classification of speech act refused strategies made by researchers is an update of the classifications made by Carla [21]. Carla with her research title "Structure of Refusals" classifies the speech act refuse strategy into two, namely the speech act of refusal directly and the speech act of refusal indirectly. For speech act of refusal directly, Carla divides it into 2, while for speech act of refusal indirectly, Carla divides it into 11, which is a statement of regret. For the purposes of this study, there are several Carla strategies that the researcher does not explain because they are not present in the speech titles being analyzed. Based on an analysis of eight speech titles in Indonesia, the following strategies were found.

Table 1. Speech Act of Refusal in Indonesia Talk Show

\begin{tabular}{|c|c|c|c|c|c|c|c|}
\hline \multirow[t]{2}{*}{ No } & \multirow[t]{2}{*}{ Talk Show } & \multicolumn{6}{|c|}{ Speech Act of Refusal } \\
\hline & & 1 & 2 & 3 & 4 & 5 & 6 \\
\hline 1. & Mata Najwa & - & 4 & 3 & 2 & - & 1 \\
\hline 2. & Alvin \& Friends & - & - & 1 & - & - & - \\
\hline 3. & $\begin{array}{l}\text { Satu Jam } \\
\text { Bersama }\end{array}$ & 1 & 1 & - & 1 & - & - \\
\hline 4. & Tea Time & - & - & - & - & - & - \\
\hline 5. & Kick Andy & - & 2 & - & - & - & - \\
\hline 6. & $\begin{array}{l}\text { Apa Kabar } \\
\text { Indonesia }\end{array}$ & - & 1 & - & - & 1 & 1 \\
\hline 7. & Sudut Pandang & - & 1 & - & 2 & - & - \\
\hline 8. & Satu Meja & - & 7 & - & - & - & - \\
\hline \multicolumn{2}{|c|}{ Total } & 1 & 16 & 4 & 5 & 1 & 2 \\
\hline \multicolumn{2}{|c|}{ Percentage } & $3,44 \%$ & $55,17 \%$ & $13,8 \%$ & $17,24 \%$ & $3,44 \%$ & $6,9 \%$ \\
\hline
\end{tabular}

Note: $\quad 1=$ speech act of refusal 
$2=$ speech act of refusal with denial

$3=$ speech act refusing clarification

$4=$ speech act of refusal with new statements

$5=$ speech act of refusal with promises in the future

$6=$ speech act of refusal with delegation of mistakes

From table 1 above it is known that there are 29 speech act of refusal that are divided into 6 strategies. The speech act strategy refusal with the denial statement appears the most is 16 speeches, this means the speech act strategy refusal the denial most often used by the speakers of the eight speech titles. The direct speech refusal strategy is 1 speech, the speech refuse strategy is clarified by 4 speeches, the speech act strategy refusal with 5 new statements, the speech act strategy refusal with a promise in the future as much as 1 speech, and the speech act strategy refusal with delegation error of 2 utterances.

\subsubsection{Speech Act of Refusal}

Madihah [8] call this strategy with the term speech act, refusal it directly with performative sentences, while researchers use the term direct speech act of refusal, the researcher changes the term for this strategy because the language is easier to understand. Speech act of refusal are strategies of refusing speech acts that directly use the word refuse or do not agree with what is said by the speech partner. Based on the results of an analysis of 8 speech titles, only 1 speech act was found refusing the speech degree Satu Jam Bersama which aired on the RTV episode "Satu Jam Bersama Susi Pudjiastuti dengan Cheryl Tanzil".

Speech made by Cheryl Tanzil as the host made the Minister of Maritime Affairs and Fisheries Susi Pudjiastuti said a refusing in the form of speech.

Susi : "Secara pribadipun saya tidak setuju dengan kita menjual pasir kepada Singapur."

\subsubsection{Speech Acts Refused by Denial}

This strategy is almost the same as the rejection strategy with non-performative statements classified by Carla [21] but the difference is the researchers add a new marker for this strategy, i.e. no. The speech act of refusing by denying is a speech act strategy of refusing by using the words of blame like not and not. Based on the results of an analysis of 8 speech titles, it was found that 16 speech acts refused which speech titles Mata Najwa which aired on the Metro TV episode "Laga Usai Pilpres" containing 4 utterances refused, Satu jam Bersama which aired on the RTV episode "Satu Jam Bersama Susi Pudjiastuti dengan Cheryl Tanzil" containing 1 utterances refused, Kick Andy which aired on the Metro TV episode "Satukan Hati Setop Bullying" containing 2 utterances refused, Apa Kabar Indonesia which aired on the TV One episode "Pilpres Belum Usai Prabowo Gugat Lagi" containing 1 utterances refused, Sudut Pandang which aired on the Metro TV episode "Kisah Anak-anak yang Tak Diinginkan" containing 1 utterances refused, and Satu Meja which aired on the Kompas TV episode "Demokrasi Setengah Hati" containing 7 utterances refused.

In the title of Mata Najwa speech, a speech uttered by guest star Arief Puyono to Adian Napitupulu made Adian speak of a strategy in the form of speech

Adian: "33 negara yang mengirimkan pemantau pemilunya sama sekali tidak satupun yang mengatakan curang, kemudian 11 njo independen dari berbagai negara asimg juga tidak ada yang mengatakan ini curang, 
kemudian 51 lembaga pemantau dalam negeri juga tidak mengatakan ini curang, lalu yang bilang ini curang siapa?"

\subsubsection{Speech Acts Refused with Clarification}

Carla [21] calls this strategy the term of remorse, but researchers prefer the term clarification. The speech act of refusing with clarification is a speech act strategy of refusing by providing clarification or explanation of why the speaker cannot approve the statement of the speech partner. Based on the results of an analysis of 8 speech titles, it was found 4 speech refuse where the speech title is Mata Najwa which aired on the Metro TV episode "Laga Usai Pilpres" containing 3 utterances refused, Alvin \& Friends which aired on the INews Tv episode "Ditanya Lawan Terberat Debat, Rocky Gerung: Tak Ada yang Setara" containing 1 utterances refused.

In Mata Najwa speech title uttered by Rocky Gerung guest star Arief Puyono made Puyono say a refusing in the form of speech.

Puyono : "Oh Jokowi Dodo itu dan Pak Maruf amin itu akan jadi presiden dan wakil presiden versinya lembaga quick count bukan lembaga KPU, jadi sama kaya di Bengkulu dia menang versi lembaga quick count bukan versi real count KPUD Bengkulu."

\subsubsection{Speech Act Refused with New Statement}

The speech act of refusing with a new statement is a strategy of the speech act of refusing by giving a new statement from what was said by the previous speech partner. So in this strategy, the speaker does not agree with the statement of the speech partner, then gives another statement in lieu of the previous statement, This researcher's opinion is in line with what is expressed by Madihah [8] according to him this strategy is a speech-refusing strategy by offering other alternatives as a substitute for the desires that are speech act of refusal. Based on the results of an analysis of 8 speech titles, it was found 5 speech refuse where Mata Najwa speech was aired on Metro TV episode "Laga Usai Pilpres" containing 2 utterances refused, Satu jam Bersama was aired on RTV episode "Satu Jam Bersama Susi Pudjiastuti dengan Cheryl Tanzil" containing 1 utterances refused, and gelar wicara Sudut Pandang was aired on Metro TV episode "Kisah Anak-anak yang Tak Diinginkan" containing 2 utterances refused.

In the speech title Sudut Pandang by Fifi Adelya Yahya the speech made Ms. Monika as the speaker say a refusing in the form of speech.

Monika : "Pergumulan tentunya karena sekalipun memang dia hamil di luar pernikahan itupun sudah merupakan sebuah kecemaran, tetap dengan melakukan aborsi, bahasanya aborsi tapi saya lebih senang ngomong pembunuhan karena itu memang pembunuhan."

\subsubsection{Speech Act Refused with Promises in the Future}

The speech act of refusing with promises in the future is a speech act strategy spoken by the speaker as a form of refusing of the wishes of the speech partner by promising to fulfill their wishes at a later time, this opinion is in line with what is expressed by Madihah [8]. Based on the results of an analysis of 8 speech titles, only 1 speech act was found refusing the speech degree Apa Kabar Indonesia was aired on TV One episode "Putusan MK Akhiri 
Sengketa Pilpres".

In the title of Apa Kabar Indonesia, the questions raised by Kamaratih Kusuma as the master of ceremonies made Andre Rosiade say a refusing with dialogue as follows.

Kamaratih : : Jadi rencananya kapan bang pertemuannya?"

Andre : "Tunggulah. Pak Jokowi lagi keluar negeri, lagi pertemuan negara j21 Pak Prabowo masih berkonsultasi dan berkonsolidasi dengan partai koalisi."

\subsubsection{Speech Act Refused with Delegation of Errors}

Madihah [8] call this strategy with speech acts refusing indirectly with avoidance, but researchers make the term speech act refusing with the delegation of mistakes because of what the speaker says in refusing the wishes of the speech partner is done by delegating errors or responsibilities to the parties other. Based on the results of an analysis of 8 speech titles, it was found 2 utterances that were refused, where as Mata Najwa talk show that aired on Metro TV episode "Laga Usai Pilpres" contained 1 speech refusing, and the title of the speech Apa Kabar Indonesia that aired on TV One episode "Pilpres Belum Usai Prabowo Gugat Lagi" contains 1 utterance.

In the title of Apa Kabar Indonesia that aired on TV One episode "Pilpres Belum Usai Prabowo Gugat Lagi", the question that was said by Putri Viola as the master of ceremonies made Abdullah, Kabiro Hukum dan Humas MA say a refusing with the dialogue as follows.

Putri : :Kapan rencananya ini akan disidangkan dan hakim juga yang akan bertugas dalam penyelesaian atau persidangan penyelesaian kasus sengketa ini siapa saja pak?"

Abdullah : "Untuk tuntut menuntut itu pada pihak yang telah ditentukan oleh UU. Mengenai tuntutan itu akan dikabulkan atau tidak itu kewenangan hakim yang menentukan, bukan kita yang berdiskusi sekarang ini."

\subsection{Refusing Speech Acts in Speech as Art of Rhetoric}

In every communication, not all speeches expressed by the speaker can be accepted by the speech partner, not infrequently the speaker refused what is said by the speech partner. Based on the results of this study it can be seen that there are many strategies that can be used to refuse the utterance of speech partners, not just the words "I do not agree with you" "I refuse your statement". So far, most speakers only use refusing speech which can threaten the face of the speech partner with negative refusing language. The strategies of refusing the degree of speech on television found in this study can be used as art in language skills (rhetoric) to refusal speech.

\section{Conclusion}

Television is believed to have a great influence on the attitudes and behavior of its audience so that it will have an impact in the short or long term. Talk shows on television can be used as a guide in developing language skills, ranging from interviewing skills, debate, and also acts of speech refuse.

Based on the results of this study, 29 speech refuse were found which were divided into 6 strategies, namely the speech act refuse strategy with a statement of denial, the direct speech 
disclaimer strategy, the speech act refuse by denying, the speech act refusing with clarification, the speech act refusing with a statement new, the speech-action strategy refuse with promises in the future, and the speech-action strategy refuses with the transfer of mistakes. The results in this study can be implied as rhetorical art in refuse a speech.

\section{References}

[1] A. A. Chaer, Sosiolinguistik. Jakarta: Rineka Cipta, 2010.

[2] J. . Searle, Speech Acts. New York: Academic Press, 1969.

[3] J. Austin, How to Do Things with Words. Cambridge: Havard University Press, 1962.

[4] G. Eelen, A Critique of Politeness Theories. Manchester: St Jerome Publishing, 2001.

[5] R. Beebe, L., Takahashi, T., and UlissWeltz, Pragmatic transfer in ESL refusals, in $R$. Scacella, E. Anderson, and S. Krashen (Eds.).Developing Communication Competence in a Second Language. New York: Newbury House, 1990.

[6] Carla, "Japanesse Refusals," Cent. Adv. Res. Languange Acquis., 2016.

[7] D. Selin, "A Contrastive Study on the Request Refusals in English By Poles and Turks," 2018.

[8] U. N. S. R. B. Madihah, "Tindak Tutur Menolak dalam Gelar Wicara Mata Najwa serta Implikasinya,” J. Kata, vol. 5, no. 2, pp. 1-12, 2017.

[9] M. A. Sharqawi and E. M. Anthony, "Analyzing the Speech Act of Disagreement Produced By Iraqi Efl Learners: a Gender Study," Humanit. Soc. Sci. Rev., vol. 7, no. 2, pp. 118-134, 2019.

[10] M. H. Ilmiani, Dwi; Wijayanto, Agus; Hikmat, "Politeness in Efl Refusals: The Comparison Between Indonesian and Thai Learners Of English," in Prosiding Konferensi Nasional, 2016, pp. 156-164.

[11] M. Kanemoto, "A Comparative Study of Refusal Assertion in the United States and Japan," Ryudai Rev. Lang. Lit., no. 38, pp. 199-212, 1993.

[12] Z. Eslami, "Refusals. How to develop appropriate refusal strategies," Speech Act Perform., no. January 2010, pp. 217-236, 2010.

[13] S. Brown, P; Levinson, Universals in Languange Usage: Politness Phenomena. Cambridge: University Press, 1978.

[14] T. V. L. Paraskevi-Lukeriya Iliadi, "REFUSAL STRATEGIES IN ENGLISH AND RUSSIAN," Rudn J. Lang. Stud. Semiot. Semant., vol. 8, no. 3, pp. 531-542, 2017.

[15] B. Hermaji, "Tindak Tutur Penerimaan dan Penolakan dalam Bahasa Indonesia," $J$. Pendidik., vol. 7, no. 1, pp. 1-10, 2013.

[16] D. F. A. D. Santoso, Wahyudi Joko; Widayanti, "Bentuk, Strategi Penggunaan, Dan Kesantunan Tindak Tutur Menolak Dalam Interaksi Antarmahasiswa Prodi Sastra Prancis Fbs Unnes," Lingua, vol. 6, no. 2, 2011.

[17] S. Maryamah, "STRATEGY OF REFUSAL SPEECH ACT IN 7 YEARS OLD CHILDREN Siti Maryamah , Arju Muti' ah , Mujiman Rus Andianto Jurusan Pendidikan Bahasa dan Seni , FKIP , Universitas Jember ( UNEJ ),” vol. 11, no. 2, pp. 479-488.

[18] J. L. Moleong, Metode Penelitian Kualitatif. Bandung: Remaja Rosdakarya, 2010.

[19] Rachman, "Tindak Tutur dalam Proses Belajar-Mengajar pada Taman Kanak-Kanak Dharma Wanita Kelurahan Wapunto Kecamatan Duruka Kabupaten Muna (Kajian Pragmatik)," in Humanika, 2015.

[20] T. Tressyalina, E. Noveria, and E. Arief, "Utilization of Indirect Speech Act In Kick Andy Talk Show as Learning Skill for Interviewer," vol. 263, no. Iclle, pp. 179-182, 
2018.

[21] Carla, "Structure of Refusals," Cent. Adv. Res. Languange Acquis., 2016. 